\title{
20. OXYGEN-ISOTOPE GEOCHEMISTRY OF DSDP LEG 34 BASALTS
}

\author{
Karlis Muehlenbachs,' Geophysical Laboratory, Carnegie Institution of Washington, Washington, D.C.
}

\begin{abstract}
Glassy basalt specimens from Hole 319A of DSDP Leg 34 have $\delta \mathrm{O}^{18}$ values identical with those of unaltered basalts dredged from mid-ocean ridges. Coarse-grained basalts are all slightly enriched in $\mathrm{O}^{18}$ owing to weathering, even though they appear fresh in hand specimen. The degree of weathering in Hole 319A, estimated according to the model of Muehlenbachs and Clayton (1972), increases from about $4 \%$ near the top to $11 \%$ near the bottom. The $\mathrm{O}^{18}$ content of all the samples is positively correlated with water content in a manner identical with that for weathered dredged basalts. Vein material is highly enriched in $\mathrm{O}^{18}$ and was probably precipitated from cold seawater. The degree of weathering is about the same for samples recovered from Hole 319A and Site 321.
\end{abstract}

\section{INTRODUCTION}

Oxygen-isotope analyses are very useful in studies of the alteration of deep-sea basalts (Garlick and Dymond, 1970; Muehlenbachs and Clayton, 1972; Pineau et al., 1973). Extensive sampling has shown that all unaltered basalts recovered from mid-ocean ridges and most oceanic islands have $\delta \mathrm{O}^{18}$ values near 5.7\% \% . Their hydrated alteration products-such as chlorite, clay, and palagonite-however, differ greatly in $\mathrm{O}^{18}$ content. The isotopic fractionation factors between alteration products and seawater are functions of temperature, the fractionations becoming smaller at higher temperatures. In many cases, not only can the degree of alteration be determined from the isotope analyses of altered basaltic material, but also the temperature at which it took place.

Authigenic clays in equilibrium with seawater at bottom temperature have $\delta \mathrm{O}^{18}$ values of 25 to $27 \%$ oo (Savin and Epstein, 1970; Garlick and Dymond, 1970). Partially weathered basalts, which are enriched in $\mathrm{O}^{18}$, can be considered mixtures of unaltered material and authigenic clays, and the amount of admixed clay or the degree of weathering can be calculated from the $\mathrm{O}^{18}$ enrichment of the basalts. Muehlenbachs and Clayton (1972) have shown that submarine basalts recovered by dredging, and presumably in contact with seawater since their solidification, weather steadily, increasing in $\mathrm{O}^{18}$ content at a rate of $0.25 \%$ per million years, or that about $1 \%$ of the basalt per million years is converted to clay.

\section{METHODS}

Oxygen was extracted from the rock powders by the $\mathrm{BrF}_{5}$ method (Clayton and Mayeda, 1963), reacted with carbon to form $\mathrm{CO}_{2}$, and analyzed on a 6-in. isotope

'Present address: Department of Geology, The University of Alberta, Edmonton, Canada T6G 2El. ratio mass spectrometer. The isotopic composition of a sample, $x$, is given as

$$
\delta_{x}=\left[\frac{\left(\mathrm{O}^{18} / \mathrm{O}^{16}\right)_{x}}{\left(\mathrm{O}^{18} / \mathrm{O}^{16}\right)_{\text {standard }}}-1\right] \times 1000
$$

The analyses are reported relative to the Standard Mean Ocean Water (SMOW) (Craig, 1961).

\section{DATA}

Oxygen-isotope analyses of 14 basalt samples from Hole 319A and Site 321 of DSDP Leg 34 are presented in Table 1, which also lists the $\mathrm{O}^{18}$ contents of some materials infilling veins. The two glassy samples, 319A$2-1,21-30 \mathrm{~cm}$ and $13-1,77-82 \mathrm{~cm}$, have $\delta \mathrm{O}^{18}$ values of 5.6 and $5.9 \%$ oo, comparable to those of all other unaltered submarine basalts which have been measured. The other basalt samples, which are coarse grained except for 321$13-4,127-132 \mathrm{~cm}$, are enriched in $\mathrm{O}^{18}, 6.6$ to $8 \%$. The $\delta \mathrm{O}^{18}$ values of the purified vein materials (Bass, 1974) are very high, $24.8 \%$.

The water contents of some of the samples have been determined and are plotted versus $\delta \mathrm{O}^{18}$ values in Figure 1.

\section{DISCUSSION}

\section{Comparison with Dredged Basalts}

The strong correlation between $\delta \mathrm{O}^{18}$ and water content in the DSDP basalts, shown in Figure 1, is identical with that in weathered, dredged basalts (Muehlenbachs and Clayton, 1972). The isotope geochemistry of the sea-floor basalts recovered by drilling or dredging is identical, leading to the conclusion that the conditions under which all these basalts were altered were the same, namely, at very low temperature (about $4^{\circ} \mathrm{C}$ ) in the presence of a large excess of seawater. If this were not the case, the alteration products of the DSDP basalts 
TABLE 1

Isotopic Composition of DSDP Leg 34 Basalts

\begin{tabular}{|c|c|c|c|c|}
\hline Hole & Core & Section & Interval (cm) & $\begin{array}{c}\delta \mathrm{O}^{18} \\
\text { (SMOW) }\end{array}$ \\
\hline \multicolumn{5}{|c|}{ Whole Rocks } \\
\hline $\begin{array}{l}319 \\
319 A \\
319 A \\
319 A \\
319 A \\
319 A \\
319 A \\
319 A \\
319 A \\
319 A \\
321 \\
321 \\
321 \\
321 \\
321\end{array}$ & $\begin{array}{r}13 \\
1 \\
2 \\
2 \\
3 \\
3 \\
3 \\
4 \\
5 \\
7 \\
13 \\
13 \\
14 \\
14 \\
14\end{array}$ & $\begin{array}{l}1 \\
1 \\
1 \\
2 \\
1 \\
3 \\
4 \\
1 \\
1 \\
1 \\
4 \\
4 \\
1 \\
3 \\
4\end{array}$ & $\begin{array}{l}77-82^{\mathrm{a}} \\
48-51 \\
21-30^{\mathrm{a}} \\
78-81 \\
32-35 \\
135-138 \\
50-53 \\
92-94 \\
51-54 \\
105-106 \\
127-132 \mathrm{pc5}^{\mathrm{b}} \\
127-132 \text { (rind) } \\
64-69 \\
1-4 \\
58-60\end{array}$ & $\begin{array}{l}5.9 \\
6.6 \\
5.6 \\
6.9 \\
7.0 \\
7.0 \\
7.3 \\
7.2 \\
7.2 \\
8.0 \\
6.8 \\
7.9 \\
6.7 \\
7.5 \\
6.7\end{array}$ \\
\hline \multicolumn{5}{|c|}{ Vein Material } \\
\hline \multicolumn{5}{|c|}{ Smectite vein: } \\
\hline \multicolumn{5}{|c|}{ Impure smectite vein, containing plagioclase: } \\
\hline $\begin{array}{l}95 \% \text { pu } \\
321 \\
80 \% \text { ch }\end{array}$ & $\begin{array}{c}14 \\
\text { orite + }\end{array}$ & $\begin{array}{l}\text { ite: } \\
3 \\
\text { goethite: }\end{array}$ & $80-100$ & 24.8 \\
\hline $\begin{array}{l}319 \text { A } \\
\text { Goethi } \\
321\end{array}$ & $\begin{array}{l}14 \\
\text { e: } \\
14\end{array}$ & 1 & 114-119 & 18.9 \\
\hline
\end{tabular}

would be lower in $\mathrm{O}^{18}$ than those of the dredged basalts, and for a given water content, the dredged basalts would be richer in $\mathrm{O}^{18}$ than the drilled basalts.

\section{Vein Material}

The above conclusions are supported by the analysis of the vein materials. The smectites $\left(\delta \mathrm{O}^{18}=24.8^{\circ} \%\right.$ ) were probably formed in equilibrium with cold seawater. If the goethite from Site 321 is comparable to that contaminating the chlorite of 319A, however, the chlorite-rich vein $\left(\delta \mathrm{O}^{18}=18.9^{\circ} \% 0\right)$ may have formed at a slightly higher temperature of a few tens of degrees $\mathrm{C}$.

\section{Weathering of the Sea Floor}

Disregarding the glassy samples, the degree of weathering of the basalts from Hole $319 \mathrm{~A}$ is fairly uniform, implying that cold seawater circulated freely for a long time to a depth of at least 40 meters in the basaltic ocean floor. The analyzed samples may not be representative of the whole basalt section because they were specifically chosen for their large grain size. Therefore, the uniformity of the $\delta \mathrm{O}^{18}$ values may result from the samples only containing 5\%-10\% easily altered component (i.e., glass) which is the only portion of the rocks weathered at any depth. Interestingly, the coarsegrained basalts from Site 321 are also 5\%-10\% weathered even though the paleontological ages of the basalt overlying sediments imply an age difference between the two holes of almost 25 m.y.

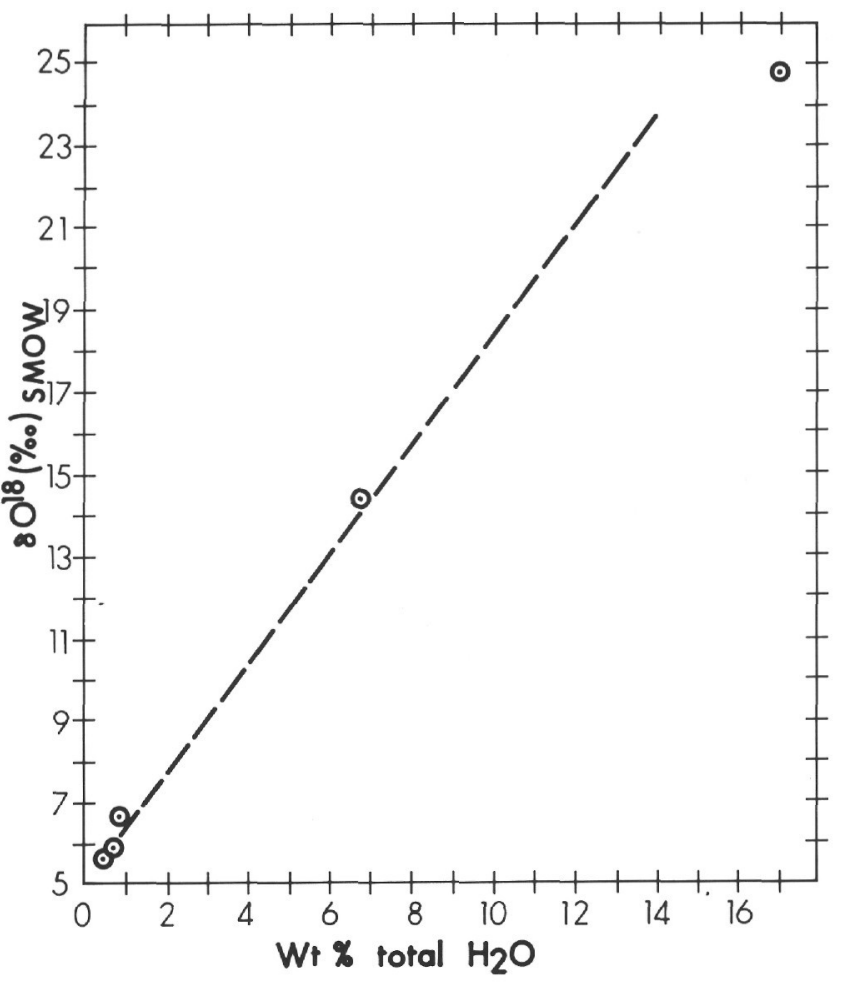

Figure 1. $\delta O^{18}$ of DSDP Leg 34 basalts versus total water content. Dashed line represents trend of weathered, dredged basalts (see Muehlenbachs and Clayton, 1972).

The similarity of the degree of weathering of the basalts from the two holes may not simply result from comparable glass contents because the bulk of the one fine-grained sample analyzed $(321-13-4,127-132 \mathrm{~cm}$, $\delta \mathrm{O}^{18}=6.8^{\circ} / 00$ ) which presumably contained a different amount of easily altered component, is, however, altered to the same degree as the coarse-grained basalts, but is bordered by a more weathered, $\mathrm{O}^{18}$-rich rind $\left(7.9^{\circ} / 00\right)$. Also, the alteration of the coarse-grained basalts from Hole 319A increases slightly with depth. Basalts near the top of the hole are about $4 \%$ weathered $\left(\delta \mathrm{O}^{18}=6.6^{\circ} / 00\right)$, whereas those near the bottom are about $10 \%$ weathered $\left(\delta \mathrm{O}^{18}=8.0^{0} \% 0\right)$. Possibly, the similarity of the weathering observed in both Hole 319A and Site 321 may imply that, after some given time, the basaltic sea floor became sealed off to the circulation of cold seawater. Perhaps that time may be estimated from the observation that the samples from DSDP Leg 34 are weathered to the same degree as are 6-m.y. old basalts dredged from midocean ridges.

\section{CONCLUSIONS}

Except for the glassy samples, all basaltic materials analyzed from DSDP Leg 34 are altered to some extent, even though superficially they may appear fresh. There is no sign of high-temperature $\left(>100^{\circ} \mathrm{C}\right)$ alteration. In Hole 319A there is a slight increase in the degree of basalt weathering with depth. Cold seawater must have had access to basalt in the oceanic crust at that site for varying lengths of time to a depth of at least 40 meters. 


\section{ACKNOWLEDGMENTS}

Dr. M.N. Bass donated the vein materials, and Dr. S.R. Hart performed the water determinations by a gas chromatographic technique.

\section{REFERENCES}

Bass, M.N., 1974. Secondary minerals in basalt, DSDP Leg 34 (abstract): Geol. Soc. Am. Abstr. with Programs, v. 6, p. 646.

Clayton, R.N. and Mayeda, T.K., 1963. The use of bromine pentafluoride in the extraction of oxygen from oxides and silicates for isotopic analysis: Geochim. Cosmochim. Acta, v. 27 , p. $43-52$.
Craig, H., 1961. Standard for reporting concentrations of deuterium and oxygen-18 in natural waters: Science, v. 133, p. 1833-1834.

Garlick, G.D. and Dymond, J.R., 1970. Oxygen isotope exchange between volcanic materials and ocean water: Geol. Soc. Am. Bull., v. 81, p. 2137-2142.

Muehlenbachs, K. and Clayton, R.N., 1972. Oxygen isotope studies of fresh and weathered submarine basalts: Canadian J. Earth Sci., v. 9, p. 172-184.

Pineau, F., Javoy, M., Craig, H., and Hawkins, J.W., 1973. $\mathrm{O}^{18} / \mathrm{O}^{16}$ and $\mathrm{C}^{13} / \mathrm{C}^{12}$ ratios in volcanic and plutonic rocks from oceanic environment (abstract): Fortschr. Miner., v. 50, suppl. 3, p. 119-120.

Savin, S.M. and Epstein, S., 1970. The oxygen and hydrogen isotope geochemistry of ocean sediments and shales: Geochim. Cosmochim. Acta, v. 34, p. 43-63. 